\title{
КРЕАТИВНИЙ ОБЛІК І АУДИТ ЕКОНОМІЧНОЇ ДІЯЛЬНОСТІ ПІДПРИЕМСТВ
}

\author{
DOI: 10.32620/cher.2019.2.11
}

Постановка проблеми. Сучасні процеси гармонізації національних облікових систем та використання світового досвіду проведення незалежного аудиту породжують необхідність широко застосовувати креативних підходів у економічній діяльності підприємств та вміло проявляти креативність до сучасного рівня розвитку бухгалтерського обліку і аудиту на підприємствах. Метою дослідження означено обгрунтування призначення креативного обліку і аудиту в умовах виробництва, універсального прояву і використання креативного потенціалу підприємств, управління знаннями, продуктивним мисленням та творчим баченням людського капіталу. Об’єктом дослідження виступає економічна діяльність підприємств різних галузей економіки України, котрі використовують креативний облік і аудит у реальній практиці господарювання. Методологічною основою дослідження стали способи і принципи наукового пізнання, загальні та спеціальні методи, прийоми, що використані у процесі обгрунтування дієвості й прикладної цінності впровадження креативного обліку і аудиту у практичній діяльності підприємств. У тому числі, методи систематизації і узагальнення використані для аналізу існуючих підходів щодо застосування креативного обліку і аудиту у різних галузях діяльності підприємств; індукції та дедукції - для обгрунтування прикладної цінності використання креативного обліку і аудиту; аналогії - для оцінювання застосування та адаптування креативного обліку та аудиту до умов функціонування сучасних підприємств, його інтелектуального потенціалу. Основною гіпотезою дослідження стало припущення, що застосування креативного обліку і аудиту в різних галузях національної економіки України не повинно порушувати встановлене законодавство, сприяти правильному формуванню i обліку фінансових показників, об’ єктивному розкриттю корисної інформації та її адаптуванню до потреб користувачів. Виклад основного матеріалу. Доведено, що методи креативного обліку і аудиту на підприємстві пов’ язані з особистістю, яка їх застосовує на основі грунтовної досвідченості, гнучкості і оригінальності мислення, логічності міркувань та інтуїтивного проникнення в суть явищ, що відбуваються на підприємстві. Тому важливою компонентою діяльності підприємств, де залучається креативний облік і аудит, стає створення умов для творчості, як самостійної цінності, наявність матеріальних і моральних стимулів професійного розвитку працівників (бухгалтерів, аудиторів); доступ усіх членів трудового колективу до інформації; демократичність та гуманізація діяльності підприємства, можливість кар'єрного росту, соціальна стабільність на підприємстві, високий рівень фінансово-економічної безпеки, становлення і розвиток загального креативного виробництва у всіх формах його прояву; взаємодія наукових, освітніх установ 3 виробництвом, швидке запровадженням новітніх; організація якісної освіти, розвинена інфраструктура отримання знань; створення стратегії розвитку підприємства, що має в наявності програми мотивацій. Запропоновані підходи мають оригінальність та практичну значимість і дозволяють спрямувати розвиток креативної компетентності з обліку і аудиту в різні освітні програми майбутніх фахівців, що навчаються за спеціальністю «Облік і оподаткування», залучення молодих науковців до досліджень, що стосуються розвитку обліку і аудиту суб' єктів господарювання в умовах креативної економіки. Проведене дослідження дозволило сформулювати висновок, що фахівці з обліку й аудиту в умовах креативної економіки повинні мати уявлення про ті проблеми, що існують сьогодні на підприємствах різних галузей; володіти необхідною інформацію, розуміти і знати яким чином слід застосовувати свої інноваційні, творчі підходи для підвищення ефективності діяльності підприємства та досягнення поставлених пріоритетів; розвивати бухгалтерську та аудиторську діяльніст ь у напрямі творчого донесення бухгалтерської інформації й фінансової звітності до усіх зацікавлених осіб, виявлення резервів виробництва та застосування неординарних, унікальних, інноваційних підходів до їх розкриття в рамках кожного окремого підприємства.

Ключові слова:

креативний облік, аудит, діяльність підприємств, розвиток, інтелектуальний потенціал.

1 Калінеску Тетяна Василівна, д-р екон. наук, професор, завідувач кафедри «Фінанси», Національний аерокосмічний університет ім. М.Є. Жуковського «Харківський авіаційний інститут», м. Харків, Україна.

Calinescu Tetyana, Doctor of Economis Sciences, Professor, Head of Finances Department National Aerospace University «Kharkiv Aviation Institute», Kharkiv, Ukraine.

ORCID ID: 0000-0003-4919-5788

e-mail: tetyana.calinescu@gmail.com 


\section{CREATIVE ACCOUNT AND AUDIT OF THE ENTERPRISES ECONOMIC ACTIVITY}

Formulation of the problem. The modern processes of harmonization the national registration systems and use of world experience of realization of independent audit are generated a necessity widely to apply creative approaches in economic activity of enterprises and able to show creative to the modern level of development of record-keeping and audit on enterprises. A research purpose is marked the ground of setting creative account and audit in the conditions of production, universal display and using of creative potential of enterprises, management of knowledge, productive thought and creative vision of human capital. As an object of research there are economic activity of enterprises the different industries comes forward economies of Ukraine, which use a creative account and audit in the real practice of manage. Methodological basis of research are became methods and principles of scientific cognition. The general and special methods and receptions are used for grounding the effectiveness, process of the applied value of the using the creative account and audit in practical activity of enterprises. Including the methods of systematization and generalization, which are used for the analysis of the existent aspects of the using the creative account and audit in different industries of enterprises activity; inductions and deductions, which are used for the grounding the applied value of the using of creative account and audit; analogies, which are used for the evaluation of application and adaptation the creative account and audit to the operating of modern enterprises conditions and its intellectual potential. The basic hypothesis of research became the supposition, that application of creative account and audit in different industries of Ukraine national economy must not violate the set legislation, assist correct forming and account of financial indexes, the objective are opened the useful information and adapted its to the necessities of users. Statement of basic material. It is wellproven that the methods of creative account and audit on an enterprise are related to personality, which applies its on the basis of same experience, flexibility and originality of thought, logic of reasoning and intuitional penetration in essence of the phenomena, which take place on an enterprise. Therefore, where a creative account and audit are attracted, conditioning becomes important parts of enterprises activity for creation, as independent to the value, presence of wage and moral incentives of professional development of workers (accountants, auditors), development of high level of internal culture of enterprise, access of all members of labor collective to information, democratization and humanizing of enterprise activity, possibility of quarry height, social stability on an enterprise, high financial and economic strength, becoming security and development of general creative production in all forms of its display; co-operating the scientific, educational establishments with a production, rapid the input of the newest, original methods and management methods in a production; organization of high-quality education, developed infrastructure of receipt the knowledge, creation of strategy the development of enterprise, which should has in a presence the program of rewards, encouragements and using the wide spectrum of stimulus the innovative creative activity. It is offered, that approach have originality and practical meaningfulness and allow to send development of creative competence from an account and audit in the different educational programs of future specialists, which study specialty "Account and taxation", bringing in of young research workers to researches, which touch development of account and audit the subjects of manage in the conditions of creative economy. The conducted research allowed to formulate a conclusion, that specialists on an account and audit in the conditions of creative economy must know about those problems, which exist today on enterprises of different industries; to own necessary information, to understand and know how it follows to apply the innovative, creative approaches for the increase of efficiency of activity of enterprise and achievement of the put priorities; to develop book-keeping and audit activity in the direction of creative report of book-keeping information and financial reporting to all interested persons, exposure of backlogs of production and application of the eccentric, unique, innovative aspects its opening in the framework of every separate enterprise.

\section{Key words:}

creative account, audit, activity of enterprises, development, intellectual potential.

\section{КРЕАТИВНЫЙ УЧЕТ И АУДИТ ЭКОНОМИЧЕСКОЙ ДЕЯТЕЛЬНОСТИ ПРЕДПРИЯТИЙ}

Постановка проблемы. Современные процессы гармонизации национальных учетных систем и использования мирового опыта проведения независимого аудита порождают необходимость широкого применения креативных подходов в экономической деятельности предприятий и умелого проявления креативности в современном уровне развития бухгалтерского учета и аудита на предприятиях. Целью исследования является обоснование предназначения креативного учета и аудита в условиях производства, выявление универсального проявления и использования креативного потенциала предприятий, управление знаниями, производительным мышлением и творческим видением человеческого капитала. В качестве объекта исследования выступает экономическая деятельность предприятий разных отраслей экономики Украины, которые используют креативный учет и аудит в 
реальной практике ведения хозяйства. Методологической основой исследования стали способы и принципы научного познания, общие и специальные методы, приемы, которые использованы в процессе обоснования действенности и прикладной ценности использования креативного учета и аудита в практической деятельности предприятий. В том числе, методы систематизации и обобщения использованы для анализа существующих подходов к использованию креативного учета и аудита в разных отраслях деятельности предприятий; индукции и дедукции - для обоснования прикладной ценности использования креативного учета и аудита; аналогии - для оценки применения и адаптации креативного учета и аудита к условиям функционирования современных предприятий и его интеллектуального потенциала. Основной гипотезой исследования стало предположение, что применение креативного учета и аудита в разных отраслях национальной экономики Украины не должно нарушать установленное законодательство, способствовать правильному формированию и учету финансовых показателей, объективному раскрытию полезной информации и адаптации ее к потребностям пользователей. Изложение основного материала. Доказано, что методы креативного учета и аудита на предприятии связаны с личностью, которая ее применяет на основе базового опыта, гибкости и оригинальности мышления, логичности рассуждений и интуитивного проникновения в суть явлений, которые происходят на предприятии. Поэтому важной компонентой деятельности предприятий, где используется креативный учет и аудит, становится создание условий для творчества, как самостоятельной ценности, наличие материальных и моральных стимулов профессионального развития работников (бухгалтеров, аудиторов), развитие высокого уровня внутренней культуры предприятия, доступ всех членов трудового коллектива к информации, демократичность и гуманизм деятельности предприятия, возможность карьерного роста, социальная стабильность на предприятии, высокий уровень финансово-экономической безопасности, становления и развитие общего креативного производства во всех формах его проявления; взаимодействие научных, образовательных учреждений с производством; быстрое внедрение новейших, оригинальных способов и методов управления в производство; организация качественного образования, развитая инфраструктура получения знаний; созданная стратегия развития предприятия, которая имеет в наличии программы мотиваций, поощрений и использования широкого спектра стимулов по отношению к инновационной творческой деятельности. Предложенные подходы имеют оригинальность, практическую иенность и позволяют направить развитие креативной компетентности по учету и аудиту в разные образовательные программы подготовки будущих специалистов, которые учатся по специальности "Учет и налогообложение"; привлекать молодых научных работников к исследованиям, которые касаются развития учета и аудита субъектов хозяйствования в условиях креативной экономики. Проведенное исследование позволило сформулировать вывод, что специалисты по учету и аудиту в условиях креативной экономики должны иметь представление о тех проблемах, которые существуют сегодня на предприятиях разных отраслей; владеть необходимой информацией, понимать и знать каким образом следует применять инновационные, творческие подходы для повышения эффективности деятельности предприятия и достижения поставленных приоритетов; развивать бухгалтерскую и аудиторскую деятельность в направлении творческого донесения бухгалтерской информации и финансовой отчетности ко всем заинтересованным лицам; выявлять резервы производства и применять неординарные, уникальные, инновационные подходы к их раскрытию в рамках каждого отдельного предприятия.

\section{Ключевые слова:}

креативный учет, аудит, деятельность предприятий, развитие, интеллектуальный потенциал.

Постановка проблеми. У доктрині розвитку національної економіки України до 2030 року передбачена креативна модель розвитку економіки [1, с. 112-123]. Саме «креативність» в цьому контексті означає появу нових, інноваційних ідей, наукових відкриттів, технологічних винаходів та технологій іiі застосування у сфері виробничої діяльності задля підвищення продуктивності праці та економічного зростання. Термін «креативність» набирає широкого застосування у сучасному баченні будь-якого розвитку, асоці- юється 3 оригінальною уявою чогось, певними знаннями, творчим сприйняттям, обробкою інформації, вмінням застосувати і поєднувати усі креативні складові із засобами комерціалізації.

Наразі не існує чіткого визначення поняття «креативності», проте можна запропонувати деяке його трактування:

a) здатність генерувати та впливати на розвиток та економічне зростання, виходячи iз креативного підгрунтя (активів) [1, с. 114]. Саме такий підхід до креативності більш до- 
речно застосовувати при розгляді креативного обліку і аудиту;

б) використання уявлень або оригінальних ідей у роботі або у створенні будь-чого [2, c. 335];

в) розпізнавання ти виробництво новизни, уміння продуктивно вирішувати складні проблеми, генерувати нові відкриття та ідеї, рішуче впроваджувати їх у практику [3, с. 253, 254].

Процеси гармонізації національних облікових систем та використання світового досвіду проведення незалежного аудиту породжують необхідність, 3 одного боку, досить широко застосовувати креативні підходи у економічній діяльності підприємств, a, 3 іншого, - вміло проявляти креативність до сучасного рівня розвитку бухгалтерського обліку і аудиту на підприємствах.

Аналіз останніх досліджень і публікацій. Стосовно креативного обліку і аудиту в Україні опубліковано достатньо робіт і всі ïx можна об'єднати у три напрями:

Перший напрям авторів дотримується позицій, що креативний облік і аудит доречно і доцільно використовувати у практичній діяльності $[4,5,6,7,8]$.

Другий - об'єднує тих, що доводять сприяння креативності існуванню формальності й шахрайству на підприємствах, тому слід запобігати розповсюдженню креативного обліку $[9,10]$.

Третій - включає ті роботи, де автори доволі лояльно відносяться до використання методів креативного обліку і аудиту і вважають, що їх застосування можливо, хоча вони i породжують механізми шахрайства на підприємствах, проте креативність слід застосовувати у якості прийомів проведення аудиту $[11,12]$.

Виходячи із вищевказаних підходів, метою статті являється обгрунтування головного призначення креативного обліку i ayдиту в умовах існування творчої економіки, виробництва; його універсального прояву i використання для розкриття креативного потенціалу підприємств, управління знаннями, продуктивним мисленням та творчим баченням людського капіталу.

Виклад основного матеріалу дослідження. Нині за Індексом глобальної креативності Україна посідає 45 позицію із 135, де оцінка здійснювалась за трьома параметрами: технологією виробництва, рівнем розвитку таланту та толерантністю $[1$, с. 118 ,
119]. Тому першочерговим завданням для України, в напрямі зміцнення рейтингу креативності, є створення умов для розвитку творчості іiі інтелектуального капіталу. На рівні СС виділяють такі види креативної економічної діяльності, що відповідають класифікації, прийнятої Свропейським парламентом, а саме сюди входять: видавнича діяльність, комп'ютерне програмування, консультації (до речі, до цього виду діяльності можна віднести облік і аудит), діяльність інформаційних служб, технічні випробування, аналіз, наукові дослідження $[1$, с. 119,120$]$ тощо. Ці сектори економічної діяльності мають найвищий прояв творчості, яка стимулює виробництво різних інноваційних матеріальних i духовних благ. Саме в цих сферах діяльності створюється сприятливі умови для розвитку й удосконалення креативного обліку і аудиту.

Узагальнюючи певний погляд науковців, бухгалтерів і аудиторів щодо застосування креативного обліку і аудиту [4-12], слід підкреслити, що це методи і прийоми, котрі не обов'язково відповідають загальній практиці, існуючим стандартам чи прийнятій обліковій політиці підприємств, виходячи із специфіки їх розвитку, проте вони не повинні порушувати встановлене законодавство, сприяти правильному формування і обліку фінансових показників, об'єктивному розкриттю корисної інформації та адаптувати іiі до потреб користувачів.

Сьогодні феномен креативності набуває значної уваги у дослідженні різних аспектів обліку і аудиту, з огляду на те, що носіями креативності є творчі особистості, що володіють новітніми методами і технологіями обліку i аудиту [3, с. 316-321]. Тому однозначно можна стверджувати, що креативність обліку i аудиту на підприємстві пов'язана 3 особистістю, яка іiї застосовує на основі грунтовної досвідченості, гнучкості та оригінальності мислення, логічності міркувань, інтуїтивного проникнення в суть явищ, що відбуваються на підприємстві. Для реалізації креативного обліку і аудиту має бути достатній інтелектуальний розвиток бухгалтера, суттєві знання, ерудиція не нижче середнього рівня [3, с. 317], що дозволяе побачити явища, котpi відбуваються на підприємстві, в іншій перспективі та мати нестандарті, нестереотипні рішення щодо подолання недоліків, виявлених в процесі аудиту.

Європейський парламент ставить перед Європейською спільнотою мету щодо поси- 
лення розвитку креативної особистості та пропонує для цього здійснення певних заходів, котрі можуть бути використані та застосовані $з$ цією ж метою в умовах функціонування українських підприємств. До них мають відношення [3, с. 319]:

підтримка розвитку особистісних, професійних, підприємницьких та соціальних навичок;

створення середовища, сприятливого для інновацій та пристосованого до швидко змінюваного внутрішнього і зовнішнього середовища підприємств;

стимулювання творчого мислення та інтуїції, починаючи 3 ранніх стадій розвитку особистості;

покращення поінформованості щодо важливості застосування креативності, інновацій, підприємницького мислення не тільки для особистого розвитку, але й економічного зростання підприємств;

поширення доступу особистості до розмаїття креативних форм самовираження, шляхом формальної освіти, неформальної і поза формальної активності;

сприяння усвідомленню в середині і поза ринком праці, що креативність, знання та гнучкість $\epsilon$ важливими в час швидких технологічних змін, покращення своїх кар'єрних можливостей, створення спроможності підприємств до інновацій;

заохочення до кращого використання творчого потенціалу і здібностей працівників.

Тому креативний розвиток бухгалтерів та аудиторів - це процес, на який впливає багато факторів, серед яких помітну роль відіграє сфера діяльності з різнорідними й неоднозначними, різноманітними і складними, внутрішніми і зовнішніми, прямими і зворотними зв'язками, що визначають орієнтири перспективного розвитку підприємств. Не маючи чітких орієнтирів досить важко проводити креативний облік і аудит, розповсюджувати їх позитивний досвід та досягати ефективного їх запровадження.

Слід приймати до уваги і той факт, що будь які інноваційні, творчі методи обліку і аудиту (в тому числі креативного) можуть бути запроваджені саме там, де залучається до праці, концентрується увага та стимулюється створення творчого середовища працівників, що може генерувати нові оригінальні ідеї та рішення, змінювати функції, форми і результати своєї діяльності. Виходячи $з$ того, що облік і аудит є логічною складовою зага- льного менеджменту підприємства, тому важливою компонентою діяльності, де залучається креативний облік і аудит, стає [3, с. 254, 255]:

1. Створення умов для творчості, як самостійної цінності, пріоритету у розвитку підприємства, що має зосереджуватися на питаннях розвитку творчого (інтелектуального) потенціалу, наявності матеріальних і моральних стимулів професійного розвитку працівників (бухгалтерів, аудиторів).

2. Розвиток високого рівня внутрішньої культури підприємства, де в основі лежить плюралізм, різноманітність думок та підходів до управління діяльністю, вільний доступ усіх членів до інформації, що стосується результатів роботи, ресурсів та різних творчих об'єднань, що створюються на виробництві.

3. Демократичність та гуманізація діяльності підприємства, що породжена терпимістю та толерантністю до всього відмінного, свободою висловлення працівниками своєї думки, можливостями кар'єрного росту, соціальною стабільністю на підприємстві, високим рівнем фінансово-економічної безпеки.

4. Становлення і розвиток загального креативного виробництва у всіх формах його прояву на підприємстві, що забезпечується, сприятливим підприємницьким кліматом, торжеством законів, тісною взаємодією наукових, освітніх установ 3 виробництвом; швидким запровадженням новітніх, оригінальних способів і методів управління у виробництво, управлінську та соціально-економічну діяльність підприємства.

5. Організація якісної освіти, що характеризує вільний доступ до отримання знань, спрямованих виключно на розвиток творчого потенціалу підприємства; наявність експертів, консультантів, тренерів та інших осіб щодо розвитку творчості, розвиненої освітньої інфраструктури; стимулювання активізації творчості, самовираження шляхом створення на підприємстві інтелектуальних груп, колективів, що можуть встановлювати загальні цінності та стратегічні пріоритети розвитку підприємства.

6. Формування стратегій розвитку підприємства, що мають в наявності програми винагород, заохочень та використовують широкий спектр стимулів щодо інноваційної творчої діяльності.

Наразі існує достатньо прикладів і різних стратегій розвитку, що приводять до успішної діяльності підприємства, створюють 
гнучкі технології виробництва [13, с. 152 173], завчасно реагують на нові вимоги ринку товарів, послуг, виробничі ситуації і т.п. Проте головним у цьому процесі $є$ наявність та створення креативних знань, використання їх при прийнятті рішень, розповсюдження та генерування нових унікальних для даного підприємства корисних знань.

В цьому контексті актуальності набуває розроблення нових креативних освітніх програм щодо спеціальності 071 «Облік і оподаткування〉 у вищих навчальних закладах, які здатні розвивати у майбутніх бухгалтерів і аудиторів творче мислення та бачення, можливість проводити творчий діалог в середині виробничого середовища та поза його межами. Створення подібних програм підійме престижність спеціальності та буде сприяти розвиненню гнучкого мислення у майбутніх спеціалістів цього напряму підготовки. Проте наша система освіти ще не готова до таких змін і впровадження оригінальних форм навчання. Моніторинг сучасної опублікованої навчальної літератури з обліку і аудиту взагалі не вміщують творчого, креативного підходу до підготовки майбутніх спеціалістів 3 обліку і оподаткування. Більш того, відомі викладачі-професіонали, які видають сучасні посібники з обліку, оподаткування і аудиту $[14$, с. $3-5 ; 15$, с. $665-669 ; 16$, с. 5-7] не тільки не використовують творчого підходу у своїй освітній діяльності, але й $є$ противниками такої креативності в освіті, бо вони закладають задатки шахрайства й перекручування інформації [17]. А, міжнародні науково-практичні конференції, що проводились 3 обліку і аудиту останніми роками в Україні $[18,19]$, навіть, не долучалися до обговорення питань креативності цих аспектів ні в освіті, ні в умовах економічної діяльності підприємств. Тому і не дивно, що за останні роки впала цікавість абітурієнтів до спеціальності «Облік і оподаткування», а до того ж, ще й прийом на бюджетну форму навчання планується Міністерством освіти і науки України в цьому році знизити майже на $10 \%$, виходячи 3 того, що ринок праці перенасичений випускниками цієї професії. Такий стан речей підкреслює необхідність наголосити на тому, що креативність в обліку і аудиті - це не дань моді, а нові знання, методи й прийоми, якими має користуватись кожен випускник спеціальності «Облік і оподаткування», бо без навичок та вмінь застосовувати творчі підходи у своїй діяльності, - далі рухатись в сучасній креативній економіці не можливо.

\section{Висновки та перспективи подалыших}

досліджень. Таким чином, існуючий погляд на креативний облік і аудит довів, що слід:

1) проводити не тільки удосконалення існуючих методик з обліку і аудиту у напрямі креативності, але й мати креативне уявлення на ті проблеми, що існують сьогодні в системі освіти, підготовки та перепідготовки кадрів для роботи на підприємствах різних галузей національної економіки;

2) креативний облік і аудит має розповсюджувати креативна сучасна особистість на підприємстві, котра володіє необхідною інформацію, розуміє і знає яким чином слід застосовувати свої інноваційні, творчі підходи для досягнення ефективної діяльності підприємства та визначених стратегічних пріоритетів;

3) освітнім установам змінити свої погляди на підготовку фахівців-бухгалтерів і аудиторів згідно існуючої концепції креативної економіки, що розвивається наразі в Україні. Необхідно створювати нові креативні освітні програми щодо підготовки фахівців для такої економічної діяльності на підприємстві, куди рекомендуються включити не тільки отримання компетентності щодо знань національних i міжнародних стандартів бухгалтерського обліку і аудиту, підготовки фінансової звітності, навколо чого сьогодні зосереджена увага противників введення і застосування креативності, але й прививати етичні, морально-психологічні компетентності, надавати вміння управляти змінами, вводити самостійні інновації та застосовувати отримані креативні знання на виробництві;

4) розвивати бухгалтерську науку не тільки в плані превалювання сутності над формою, бюрократичного, об'єктивного відображення реального стану речей на підприємстві, а і у напрямі творчого донесення бухгалтерської інформації й фінансової звітності до усіх зацікавлених осіб, виявлення резервів виробництва та застосування неординарних, унікальних, інноваційних підходів до їх розкриття в рамках кожного окремого підприємства.

5) зосередити увагу на тому, що бухгалтер - це перша особа, що разом з керівником підприємства підписує усі бухгалтерські, фінансові, прогнозні та стратегічні документи щодо розвитку підприємства. Тому отримання кваліфікації бухгалтера й аудитора, на- 
вчаючись на першому рівні (бакалаврському) чи другому (магістерському) має бути престижною і кар'єрною орієнтацію для майбутніх абітурієнтів, не зважаючи на те, що сьогодні стати бухгалтером можна закінчивши будь-які піврічні курси і освоїти користування існуючими планами рахунків, стандартами та іншими законодавчими документами. Проте ніякі курси не дадуть креативні знання майбутньому бухгалтеру - першому керівнику підприємства , який бачить перспективу розвитку, знає як досягати поставлені цілі та залучити до своєї діяльності усіх зацікавлених осіб.

Тому отримані результати дослідження будуть спрямовані саме на розвиток тих креативних компетентностей, які слід розвивати, використовувати та запроваджувати в освітні програми майбутніх фахівців, що навчаються за спеціальністю «Облік і оподаткування» та залучення молодих креативних науковців до досліджень, що стосуються розвитку обліку і аудиту суб'єктів господарювання в умовах кризових явищ.

\section{Література}

1. Україна 2030: Доктрина збалансованого розвитку. - Львів: Кальварія, 2017. - 168 с.

2. Concise Oxford English Dictionary. Edited by C. Soanes, A. Stevenson. - New York: Oxford University Press, 2009. - 1681 p.

3. Розвиток інформаційного суспільства: колективна монографія в 10-ти томах / Том 9. Правові та соціально-психологічні виміри новітнього інформаційного суспільства. - К.: ВНЗ «Університет економіки і права «Крок», 2015. $424 \mathrm{c}$.

4. Хомін П. Я. Креативний податковий облік: методологічні основи уніфікації з фінансовим обліком / П. Я. Хомін. [Електронний ресурс]. - Режим доступу: http://ena.lp.edu.ua

5. Левицька С. О. Креативність бухгалтерського обліку на етапах формування збалансованості соціально-економічного розвитку / C.О. Левицька // Наукові записки Національного університету «Острозька Академія». Серія «Економіка»: науковий журнал. - Острог: Видво НУ «ОА», вересень 2017. - №6 (34). - С. 89 94.

6. Кравченко М. А. Розвиток призначення креативного обліку в міжнародних стандартах фінансової звітності / М.А. Кравченко // Науковий вісник Херсонського державного університету. Серія «Економічні науки». - Випуск 14. Частина 3, 2015. - С. $152-157$.
7. Пушкар М. С. Креативний облік - благо для бізнесу і суспільства / М. С. Пушкар. [Електронний ресурс]. - Режим доступу: http://dspace.tneu.edu.ua/bitstream/316497/16096/ 1/36-39.pdf

8. Подолянчук О. А. Сутність креативного обліку / О. А. Подолянчук // Бухгалтерський облік, оподаткування, аналіз і аудит: сучасний стан, проблеми та перспективи розвитку: III Міжнародна науково-практична конференція (Чернігів, 27 листопада 2017 р.): тези доповідей. - Чернігів: ЧНТУ, 2017. - С. 8-10.

9. Голов С. Ф. Креативний облік: творчість чи шахрайство? / С. Ф. Голов // Економічні науки. Серія «Облік і фінанси». - 2010. - Випуск 7(25). Ч. 1. - С. 360-367.

10. Мамишев А. В. Ризикоорієнтований підхід до виявлення аудиторами фінансових шахрайств i злочинів із відмивання грошей / А.В. Мамишев // Фінанси України. - 2013. №4. - C. 80-88.

11. Мокринська 3. В. Творчий підхід у бухгалтерському обліку чи проблеми етики бухгалтера / 3. В. Мокринська // Агросвіт. - 2015. - №6. - C. 31-35.

12. Олійник C. О. Роль креативного обліку та його прояви / С. О. Олійник // Науковий огляд. - 2018. - № 7(50) [Електронний ресурс]. - Режим доступу: http://oaji.net/articles/2017/797-1537549073.pdf

13. Калінеску T. В. Оцінювання гнучкості інноваційного розвитку підприємств та виробничого персоналу: монографія / Т. В. Калінеску, О. Д. Кирилов, А. О. Фоменко. - Сєвєродонецьк: вид-во СНУ ім. В. Даля, 2016. -316 с.

14. Плаксієнко В. Я. Облік, оподаткування та аудит. Навч. посіб. / В. Я. Плаксієнко, Ю. А. Верига, В. А. Кулик, Є. А. Карпенко. - К.: Центр навчальної літератури, 2019. - 509 с.

15. Лишиленко O. В. Бухгалтерський облік. Підручник - К.: Центр навчальної літератури, 2017. $-670 \mathrm{c}$.

16. Лень B. С. Бухгалтерський облік в Україні. Основи та практика. Навчальний посібник / В.С. Лень, В.В. Гливенко. - К.: Центр навчальної літератури, 2018. - 608 с.

17. Голов С. Ф. Креативний облік - загроза професії та суспільству / С. Ф. Голов // Бухгалтерський облік і аудит. - 2011. - №1. - С. 31-40.

18. Бухгалтерський облік, оподаткування, аналіз і аудит: сучасний стан, проблеми та перспективи розвитку: III Міжнародна науковопрактична конференція (Чернігів, 27 листопада 2017 р.): тези доповідей. - Чернігів: ЧНТУ, 2017. -204 c. 
19. Матеріали міжнародної науковопрактичної конференції до 20 річчя кафедри обліку і аудиту ІФНТУНГ «Сучасний стан, актуальні проблеми та перспективи розвитку, обліку, контролю. та аналізу». Тези доповідей. М. Івано-Франківськ, 16-17 жовтня 2015 р. - Івано-Франківськ: ІФНТУНГ. 2015. - 350 с.

\section{Reference}

1. Ukraine is 2030: Doctrine of the balanced development (2017). Lviv: Kalvaria, 168.

2. Concise Oxford English Dictionary. (2009). By editors C. Soanes, A. Stevenson. New York: Oxford University Press, 1681.

3. Development of informative society: collective monograph in 10-ти volumes. Tom 9. Legal and social and psychological measuring of the newest informative society. (2015). Kyiv: HEE "University of economy and legal "Step", 424.

4. Khomyn, P. Y. (2014). Creative Tax Accounting: Methodological Foundation Unification Accounting. Electronic source (Web publication). Retrieved from: http://ena.lp.edu.ua

5. Levytska, S. (2017). Creativity in Accounting at the Stage of the Social-Economic Development Sustainability. Scientific Messages National University of "Ostrozka Academy". Series "Economy": Scientific magazine. Ostrog: Published NU "OA", September, 6 (34), 89-94.

6. Kravchenko, M. A. (2015). Development of Setting of Eccentricness account is in the International Standards of the Financial Reporting. Scientific Announcer of the Kherson State University. Series "Economic sciences". Producing 14. Part 3, 152-157.

7. Pushkar, M. S. (2014). Creative accountblessing for business and society. Retrieved from: http://dspace.tneu.edu.ua/bitstream/316436-39.pdf

8. Podolianchyk, O. A. (2017). Essence of creative account. In a book: Record-keeping, taxation, analysis and audit: the modern state, problems and prospects of development: III International scientifically and practical conference (Chernihiv, November, 27): Theses. Chernihiv: CNTU, 8-10.

Стаття надійшла

до редакції : 05.05.2019 p.
9. Gholov, S. F. (2010). Creative account: creation or swindle? Economic sciences. Series "Account and finance", Producing 7(25), P. 1, 360-367.

10. Mamyshev, A. V. (2013). Risk oriented aspects to espousing the auditors the financial swindles and crimes public accountants from washing money. Finances of Ukraine, 4, 80-88.

11. Mokrynska, Z. V. (2015). Creativity in Accounting or Issues of Bookkeeper Ethics. Agroworld, 6, 31-35.

12. Oliinyk, S. O. (2018). Role of creative account and its displays. The Scientific review. International scientific magazine, 7(50). Retrieved from: http://oaji.net/articles/2017/7971537549073.pdf

13. Calinescu, T. V. \& Kyrylov, O. D. \& Fomenko, A. O. (2016). Evaluation of flexibility the innovative development of enterprises and manufacturing personnel. Severodonetsk: Printed Volodymyr Dahl East Ukrainian National University, 316.

14. Plaksienko, V. I, \&. Veriga, Y.A. \& Kulik, V.A. \& Karpenko, E.A. (2019). Account, taxation and audit. Textbook. Kyiv: Centre of educational literature, 509.

15. Lyshylenko, O.V. (2017). Recordkeeping. Kyiv: Centre of educational literature, 670 .

16. Len, B. S. \& Glyvenko, V. V. (2018). A record-keeping in Ukraine. Bases and practice. Textbook. Kyiv: Centre of educational literature, 608.

17. Gholov, S. F. (2011). Creative account is a threat of profession and society. Record-keeping and audit, $1,31-40$.

18. Record-keeping, taxation, analysis and audit: the modern state, problems and prospects of development: III International scientifically and practical conference (Chernihiv, November, 27): Theses. (2017). Chernihiv: CNTU, 204.

19. Materials of international scientific and practice conference to 20 anniversary of account and audit department of IFNTUOG "Modern state, actual problem and prospects of development, account, control and analyze". Theses of reports. Ivano-Frankivsk, October, 16-17. (2015). IvanoFrankivsk: IFNTUOG, 350.

Стаття прийнята

до друку: 26.06.2019 p.

Бібліографічний опис для цитування :

Калінеску Т. В. Креативний облік i аудит економічної діяльності підприємств / Т. В. Калінеску // Часопис економічних реформ. - 2019. - № 2 (34). - С. $95-102$. 